\title{
Expression of survivin in adenoid cystic carcinoma of the lacrimal gland and the effect of intervention with arsenic trioxide in vitro
}

\author{
YINGZHE PAN $^{1}$, YIQIAO XING ${ }^{2}$ and HUI WANG ${ }^{1}$ \\ ${ }^{1}$ Department of Xiangyang Hospital, Hubei University of Medicine, Xiangyang, Hubei 441000; \\ ${ }^{2}$ Department of Ophthalmology, Renmin Hospital of Wuhan University, Wuhan, Hubei 430060, P.R. China
}

Received July 22, 2014; Accepted March 20, 2015

DOI: $10.3892 / \mathrm{etm} .2015 .2466$

\begin{abstract}
The aim of the present study was to investigate the role of survivin in adenoid cystic carcinoma of the lacrimal gland (LGACC) and the effect of arsenic trioxide $\left(\mathrm{As}_{2} \mathrm{O}_{3}\right)$ intervention in vitro. In total, 13 patients with $\mathrm{LGACC}$ were recruited from Renmin Hospital of Wuhan University between 2007 and 2012. The patients were divided into different groups, namely tumor-node-metastasis (TNM)1-2 and TNM3-4, according to the TNM classification. A total of eight samples were included in the TNM1-2 group, while five samples were included in the TNM3-4 group. In addition, six patients that suffered from other diseases (no tumor), but underwent eye surgery, were selected as the controls. The mRNA and protein expression levels of survivin were analyzed. In addition, primary adenoid cystic carcinoma (ACC) cells were cultured and the expression of survivin was silenced using short interfering RNA (siRNA), after which the cell proliferation was determined. Furthermore, the primary cultured ACC cells were treated with different doses of $\mathrm{As}_{2} \mathrm{O}_{3}$ to observe the effect on the apoptosis rate. The mRNA and protein expression levels of survivin in the LGACC groups were higher when compared with the controls $(\mathrm{P}<0.01)$. In addition, the expression levels were higher in the TNM3-4 group when compared with the TNM1-2 group ( $\mathrm{P}<0.01)$. After silencing survivin expression using siRNA, the rate of ACC cell proliferation was shown to decrease at days 2, 3, 4 and 5 following culture, particularly in the TNM3-4 group at days 2 and 3 ( $\mathrm{P}<0.05)$, day 4 ( $\mathrm{P}<0.01$ vs. TNM1-2 + siRNA); and days 3 and $5(\mathrm{P}<0.05)$, and day $2(\mathrm{P}<0.01$ vs. TNM3 $-4+$ siRNA). The mRNA expression levels of survivin in the TNM1-2 and TNM3-4 groups were significantly decreased following treatment with the various doses of $\mathrm{As}_{2} \mathrm{O}_{3}(2,4$ and $6 \mu \mathrm{M})$ for $48 \mathrm{~h}$, and the apoptosis rate of the ACC cells was markedly increased (TNM1-2 and 3-4: $\mathrm{As}_{2} \mathrm{O}_{3} 6 \mu \mathrm{M}$ vs. $\mathrm{As}_{2} \mathrm{O}_{3} 2 \mu \mathrm{M}, \mathrm{As}_{2} \mathrm{O}_{3} 6 \mu \mathrm{M}$
\end{abstract}

Correspondence to: Professor Yiqiao Xing, Department of Ophthalmology, Renmin Hospital of Wuhan University, 238 Jiefang Road, Wuhan, Hubei 430060, P.R. China

E-mail: xyqdr07@aliyun.com

Key words: lacrimal gland, adenoid cystic carcinoma, survivin, arsenic trioxide vs. $\mathrm{As}_{2} \mathrm{O}_{3} 4 \mathrm{Mm}, \mathrm{P}<0.01 ; \mathrm{TNF} 3-4, \mathrm{As}_{2} \mathrm{O}_{3} 4 \mu \mathrm{M}$ VS. $\mathrm{As}_{2} \mathrm{O}_{3}$ $2 \mu \mathrm{M}, \mathrm{P}<0.01$; TNM1-2, $\mathrm{As}_{2} \mathrm{O}_{3} 4 \mu \mathrm{M}$ vs. $\left.\mathrm{As}_{2} \mathrm{O}_{3} 2 \mu \mathrm{M}, \mathrm{P}<0.05\right)$. Therefore, survivin was demonstrated to be highly expressed in ACC cells of the lacrimal gland, and inhibition of survivin gene expression was found to suppress the proliferation of the ACC cells. Furthermore, $\mathrm{As}_{2} \mathrm{O}_{3}$ treatment was demonstrated to inhibit the mRNA expression of survivin in the ACC cells, while significantly increasing the apoptosis rate.

\section{Introduction}

Adenoid cystic carcinoma (ACC) is rare form of cancer that is not often observed in clinical practice, accounting for $\sim 1 \%$ of head and neck malignant tumors. The tumors are most commonly observed in the salivary gland, nasal cavity and sinus, as well as the lacrimal gland (1). Adenoid cystic carcinoma of the lacrimal gland (LGACC) is one of the most common types of malignant epithelial tumor in the lacrimal gland, with an incidence of $29 \%$. In spite of the low clinical incidence, ACC is difficult to be cured and relapse is common following surgery due to the high malignant degree and strong invasion capacity in local tissue. Local lymph node metastasis is rare; however, long distance metastasis is very common (2). In addition, the five-year survival rate is relatively high; however, the survival rate between 10 and 20 years is considerably reduced $(3,4)$. ACC originating from the lacrimal gland had a higher tendency to invade the cranial cavity, as compared with tumors from the salivary gland, and the corresponding incidence rate is between 4 and 22\% (5).

However, the current early diagnosis and treatment is far from achieving the considerable clinical requirement. The majority of antitumor drug-mediated cell death occurs via the suppression of cell proliferation and the induction of apoptosis. As a typical anti-apoptosis protein, survivin is characterized by inhibitory functions with regard to cell apoptosis and the regulation of cell division (6). Survivin has also been shown to affect the biological behavior of tumors via inhibiting apoptosis, participating in cellular division and promoting neovascularization, and the protein has been recognized as one of the most powerful anti-apoptosis factors $(7,8)$. In addition, a previous study demonstrated that normal tissue does not express survivin, while the protein is predominantly and specifically expressed in tumor tissues (9). Arsenic trioxide $\left(\mathrm{As}_{2} \mathrm{O}_{3}\right)$ has been demonstrated to induce the apoptosis of ACC-2 cells (10). 


\section{Materials and methods}

Patients and specimens. In total, 13 patients with LGACC (female, 4; male, 9) were recruited from Renmin Hospital of Wuhan University (Wuhan, China) between 2007 and 2012. None of the patients had undergone any chemotherapy, radiotherapy or hormonotherapy prior to surgery. On the basis of the 7th edition of the American Joint Committee on Cancer TNM Classification for Lacrimal Gland Tumors stages, the 13 patients were divided into two groups, namely the TNM1-2 and TNM3-4 groups. In total, eight samples comprised the TNM1-2 group, while five samples were included in the TNM3-4 group. Primary cells were obtained using tissue culture techniques. Mixed cells were removed via a number of methods and cell morphological characteristics were observed using a phase contrast microscope. In addition, normal lacrimal gland tissues were collected from six patients who underwent eye surgery as a result of a non-tumor-induced disease during the same time period. All the patients provided informed consent and the experiment was approved by the Ethics Committee of Renmin Hospital of Wuhan University.

Reverse transcription-quantitative polymerase chain reaction $(R T-q P C R)$. The mRNA expression levels of survivin were examined using RT-qPCR, and the primers used are shown in Table I. $\beta$-actin was used as a control. Total RNA was isolated with TRIzol reagent (Invitrogen Life Technologies, Carlsbad, CA, USA) and treated with RNase-free DNase I (Takara Bio, Inc., Shiga, Japan) to avoid genomic DNA contamination. Yields and purities were estimated using the A260/A280 ratio using a NanoDrop 2000c spectrophotometer (Thermo Fisher Scientific, Waltham, MA, USA). Samples with an absorbance ratio of 1.9-2.0 were reverse transcribed using a Revert Aid First-Strand cDNA Synthesis kit (Thermo Fisher Scientific) with a random hexamer primer (Shanghai Sangon Biotechnology Co., Ltd., Shanghai, China). PCR amplification of the cDNA template was conducted using Thunderbird SYBR qPCR mix (Toyobo Co., Ltd., Osaka, Japan) on an ABI PRISM 7300 sequence detection system (Applied Biosystems Life Technologies, Carlsbad, CA, USA). The conditions for PCR were as follows: Initial denaturation at $95^{\circ} \mathrm{C}$ for $5 \mathrm{~min}$, followed by 40 amplification cycles consisting of denaturation at $95^{\circ} \mathrm{C}$ for $5 \mathrm{sec}$, annealing at $58^{\circ} \mathrm{C}$ for $30 \mathrm{sec}$ and elongation at $72^{\circ} \mathrm{C}$ for $30 \mathrm{sec}$. PCR assays were run in triplicate, and the results were averaged. All PCR products were visualized by electrophoresis and ethidium bromide staining in $2 \%$ agarose gels. The relative expression level of the genes was normalized against an internal $\beta$-actin control, using the ddCt method.

Western blot analysis. For western blot analysis, $50 \mu \mathrm{g}$ protein was loaded per well on a $12 \%$ sodium dodecyl sulfate-polyacrylamide electrophoresis gel and resolved via standard electrophoresis. Subsequently, the gels were electrophoretically transferred onto nitrocellulose membranes (Bio-Rad Laboratories, Inc., Hercules, CA, USA). The membranes were blocked with 5\% bovine serum albumin (Sigma-Aldrich, St. Louis, MO, USA) in phosphate-buffered saline (PBS) containing $0.1 \%$ Tween-20 (PBS-T) for $1 \mathrm{~h}$ at room temperature. Next, the membranes were probed overnight at $4^{\circ} \mathrm{C}$ with polyclonal antibodies targeting survivin $(1: 800 ; 2803$; Cell
Signaling Technology, Inc., Danvers, MA, USA) and $\beta$-actin (1:600; 4967; Cell Signaling Technology, Inc.). Protein molecular weight markers were included on each blot. To verify that equivalent amounts of the protein samples were loaded, the membranes were probed overnight at $4^{\circ} \mathrm{C}$. Subsequently, the membranes were extensively washed in PBS-T and incubated with a peroxidase-conjugated anti-rabbit $\operatorname{IgG}(1: 3,000 \mathrm{w} / \mathrm{v}$; \#8888; Cell Signaling Technology, Inc., Danvers, MA, USA) to reveal the presence of the survivin and $\beta$-actin primary antibodies. The bands were visualized using an enhanced chemiluminescence kit (PerkinElmer, Inc., Waltham, MA, USA), and their optical densities were measured using the Densitometry Function in the Scion Image software for Windows, beta version 4.02 (NIH Image programme).

Cell culture. Primary human ACC cells and normal cells of the lacrimal gland were prepared and cultured, as described previously (10), with certain minor modifications. The lacrimal gland was decapsulated to remove the majority of other tissues, and the remaining tissue was minced and digested with $1.0 \mathrm{~g} / 1$ collagenase I (\#C0130) and $5.0 \mathrm{mg} / \mathrm{l}$ DNase I (\#D5025; Sigma-Aldrich) in Dulbecco's modified Eagle's medium (\#SH30023.01B, HyClone, Logan, UT, USA): Nutrient mixture F-12 (DMEM/F12) at $37^{\circ} \mathrm{C}$ for $15 \mathrm{~min}$. The supernatants were diluted with modified DMEM/F12 medium, which contained 10\% fetal bovine serum (\#SH30084.03; HyClone). Subsequently, the mixtures were centrifuged at $60 \mathrm{x} \mathrm{g}$ for $8 \mathrm{~min}$ at $4^{\circ} \mathrm{C}$, and the resulting cell pellets were resuspended in medium and repelleted, as aforementioned. The cells were plated at a density of $\sim 1 \times 10^{6}$ cells $/ \mathrm{ml}$ in six-well plates and incubated in a humidified atmosphere of $5 \% \mathrm{CO}_{2}$ at $37^{\circ} \mathrm{C}$ until the cells had adhered. Six replicates were used. After $24 \mathrm{~h}$, the medium was replaced ( $2 \mathrm{ml} /$ well).

RNA interference. Primer sequences for survivin were as follows: Forward, 5'-CCCGTTGGCAGAGGTGGC-3' and reverse, 5'-TGGGACCAGGCAGCTCCG-3'. Specific short interfering RNA (siRNA) fragments of survivin were obtained using a BLOCK-iT ${ }^{\mathrm{TM}}$ Complete Dicer RNAi kit (Invitrogen Life Technologies). Subsequently, the ACC cells of the lacrimal gland were transfected with $25 \mathrm{ng}$ siRNA using $5 \mathrm{ml}$ Lipofectamine 2000 (Invitrogen Life Technologies). At $48 \mathrm{~h}$ after transfection, the cells were collected for the subsequent RT-qPCR and MTT assays.

$\mathrm{As}_{2} \mathrm{O}_{3}$ treatment. $\mathrm{As}_{2} \mathrm{O}_{3}$ treatment was applied following the adoption and modification of a previous method (10). Cells in an exponential growth phase were cultured in serum-free medium for $24 \mathrm{~h}$, after which the cells were seeded into three independent six-well plates and treated with $0,2,4$ and $6 \mu \mathrm{M}$ $\mathrm{As}_{2} \mathrm{O}_{3}(200 \mu \mathrm{l}$ per well) for 24,48 and $72 \mathrm{~h}$.

MTT assay. Following $\mathrm{As}_{2} \mathrm{O}_{3}$ treatment for 24 and $48 \mathrm{~h}$, cell survival was determined using an MTT assay. The cells were cultured in 96 well-plates at a density of $1 \times 10^{4}$ cells per well. A $20-\mu 1$ volume of MTT solution $(5 \mathrm{mg} / \mathrm{ml})$ was added to each well and subsequently incubated for $4 \mathrm{~h}$ at $37^{\circ} \mathrm{C}$. Following removal of the medium, the formazan salts were dissolved in $100 \mu \mathrm{l}$ dimethyl sulfoxide and the optical absorbance was determined using a microplate reader at a wavelength of $490 \mathrm{~nm}$ 
Table I. Primers used for reverse transcription-quantitative polymerase chain reaction.

\begin{tabular}{lll}
\hline Gene & \multicolumn{1}{c}{ Forward primer } & Reverse primer \\
\hline $\begin{array}{l}\text { Survivin } \\
\beta \text {-actin }\end{array}$ & CCCAGCACAATGAAGATCAAGATCAT & ATCTGCTGGAAGGTGGACAGCGA \\
\hline
\end{tabular}
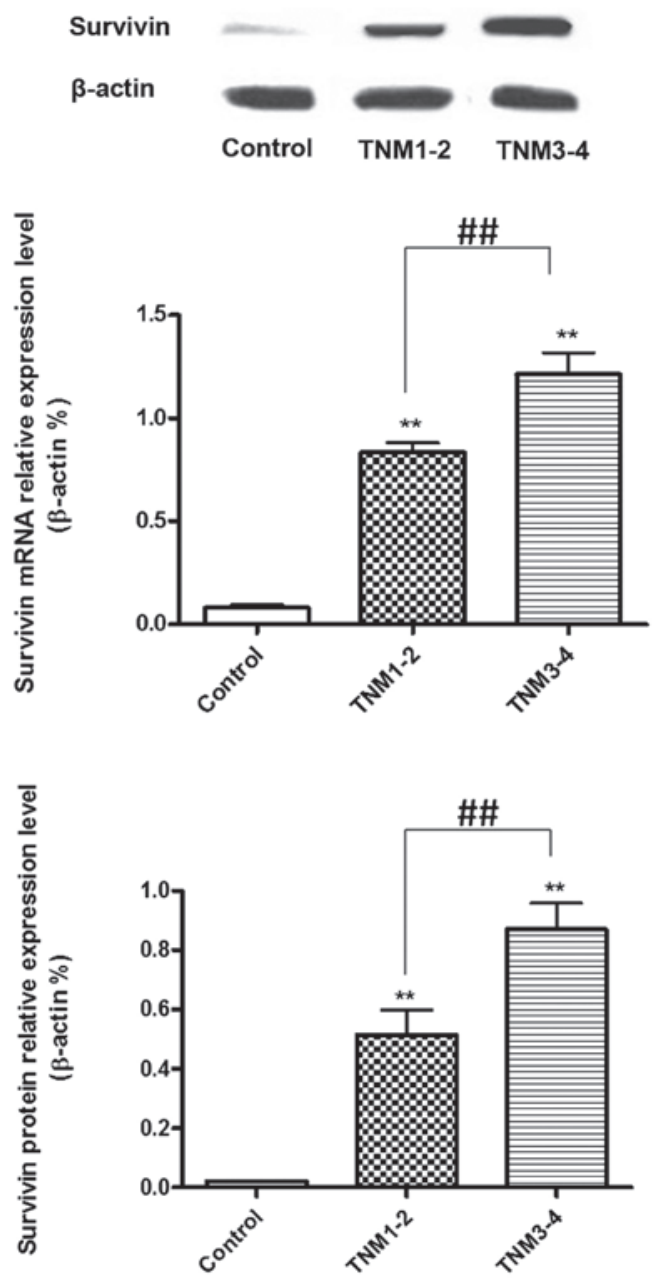

Figure 1. Relative mRNA and protein expression levels of survivin in human adenoid cystic carcinoma tissues from the lacrimal gland. Results are expressed as the mean \pm standard deviation $(n=5) .{ }^{* *} \mathrm{P}<0.01$, vs. control; ${ }^{\# \#} \mathrm{P}<0.01$, vs. TNM1-2. TNM, tumor-node-metastasis.

(BioTek Instruments, Inc., Winooski, VT, USA). Cell viability was expressed as a percentage of the corresponding control.

Statistical analysis. All data were expressed as the mean \pm standard error of the means. Comparisons between two groups were performed using the unpaired Student's $t$-test. Differences among groups were determined using one-way analysis of variance followed by Student-Newman-Keuls tests. $\mathrm{P}<0.05$ was considered to indicate a statistically significant difference.

\section{Results}

mRNA and protein expression levels of survivin in tumor tissues collected from LGACC patients with a different patho-

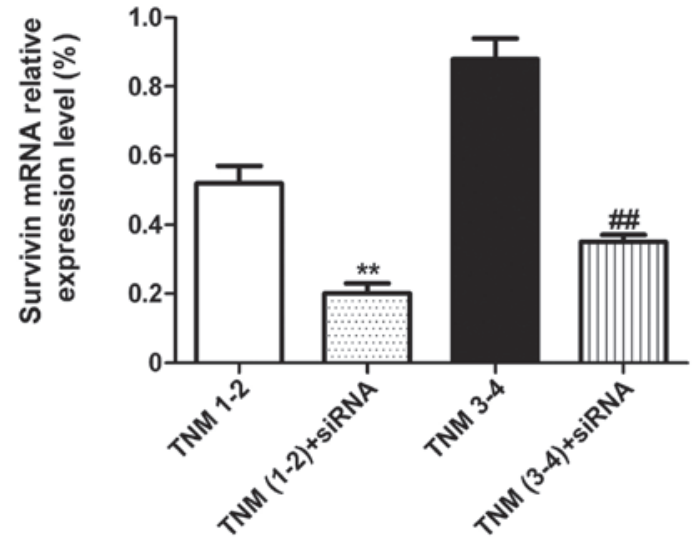

Figure 2. Relative mRNA expression levels of survivin in primary human adenoid cystic carcinoma cells from the lacrimal gland following treatment with siRNA for $48 \mathrm{~h}$. Results are expressed as the mean \pm standard deviation $(n=5) .{ }^{* *} \mathrm{P}<0.01$, vs. TNM1-2; ${ }^{\# \#} \mathrm{P}<0.01$, vs. TNM3-4. TNM, tumor-node-metastasis; siRNA, short interfering RNA.

logical classification. The mRNA and protein expression levels of survivin in the TNM1-2 and TNM3-4 groups were higher when compared with the control samples $(\mathrm{P}<0.01)$. In addition, when comparing the TNM groups, the TNM3-4 patients exhibited higher mRNA and protein expression levels of survivin when compared with the TNM1-2 patients ( $\mathrm{P}<0.01$; Fig. 1$)$.

Effects of siRNA interference on the $m R N A$ expression of survivin and the cell proliferation of primary cultured LGACC cells. At $48 \mathrm{~h}$ after siRNA interference, the mRNA expression levels of survivin in the TNM1-2 and TNM3-4 groups were significantly decreased when compared with the non-siRNA interference group $(\mathrm{P}<0.01$; Fig. 2). Furthermore, the rate of cell proliferation in the TNM1-2 group was shown to decrease following siRNA treatment, and the cell viability percentages at days 2, 3 and 4 were all lower when compared with the non-siRNA interference control (days 2 and 3, $\mathrm{P}<0.05$; day 4, $\mathrm{P}<0.01$ vs. TNM1-2 + siRNA). The rate of cell proliferation in the TNM3-4 group was also significant decreased following siRNA treatment, and the cell viability percentages at days 2,3 and 5 were all lower when compared with the non-siRNA interference control (days 3 and $5, \mathrm{P}<0.05$; day $2, \mathrm{P}<0.01$ vs. TNM3-4 + siRNA; Fig. 3).

Effects of different doses of $\mathrm{As}_{2} \mathrm{O}_{3}$ treatment on the mRNA expression levels of survivin. At $48 \mathrm{~h}$ after treatment with various doses of $\mathrm{As}_{2} \mathrm{O}_{3}(2,4$ and $6 \mu \mathrm{M})$, the mRNA expression levels of survivin in the TNM1-2 group were significantly decreased when compared with the control $(\mathrm{P}<0.05, \mathrm{P}<0.01)$. Furthermore, $\mathrm{As}_{2} \mathrm{O}_{3}$ treatment was shown to dose-dependently decrease the mRNA expression levels of survivin in the 

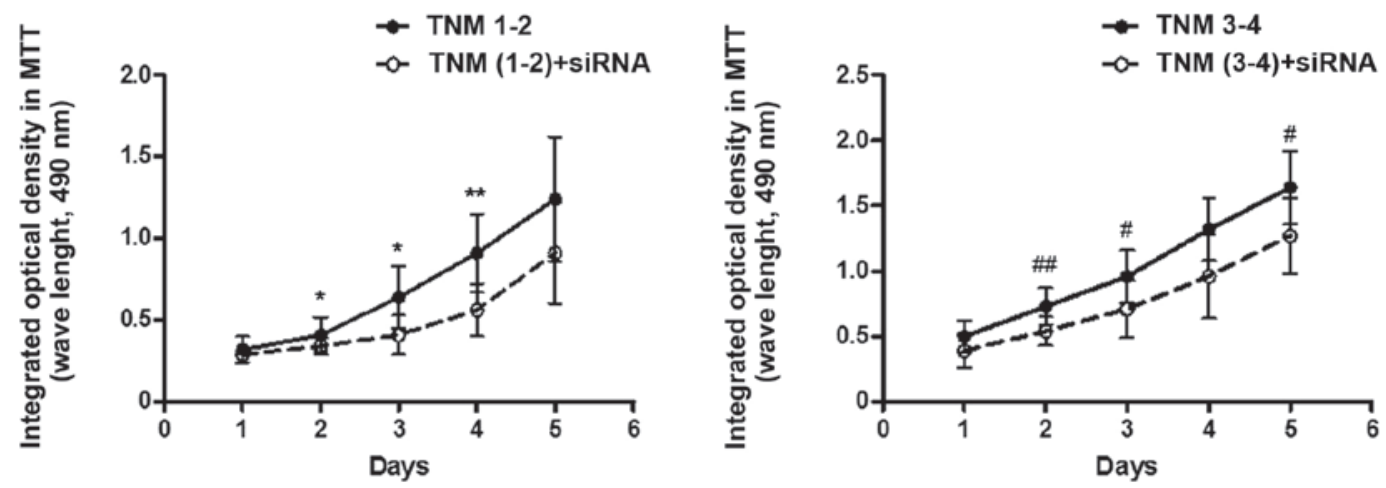

Figure 3. Integrated optical density values obtained in the MTT assay prior to and following siRNA treatment in the TNM1-2 and TNM3-4 cells. Results are expressed as the mean \pm standard deviation $(n=5)$. ${ }^{\mathrm{P}}<<0.05$ and ${ }^{* *} \mathrm{P}<0.01$, vs. TNM $(1-2)+\operatorname{siRNA} ;{ }^{*} \mathrm{P}<0.05$ and ${ }^{\# \prime} \mathrm{P}<0.01$, vs. TNM $(3-4)+\operatorname{siRNA}$. TNM, tumor-node-metastasis; siRNA, short interfering RNA.
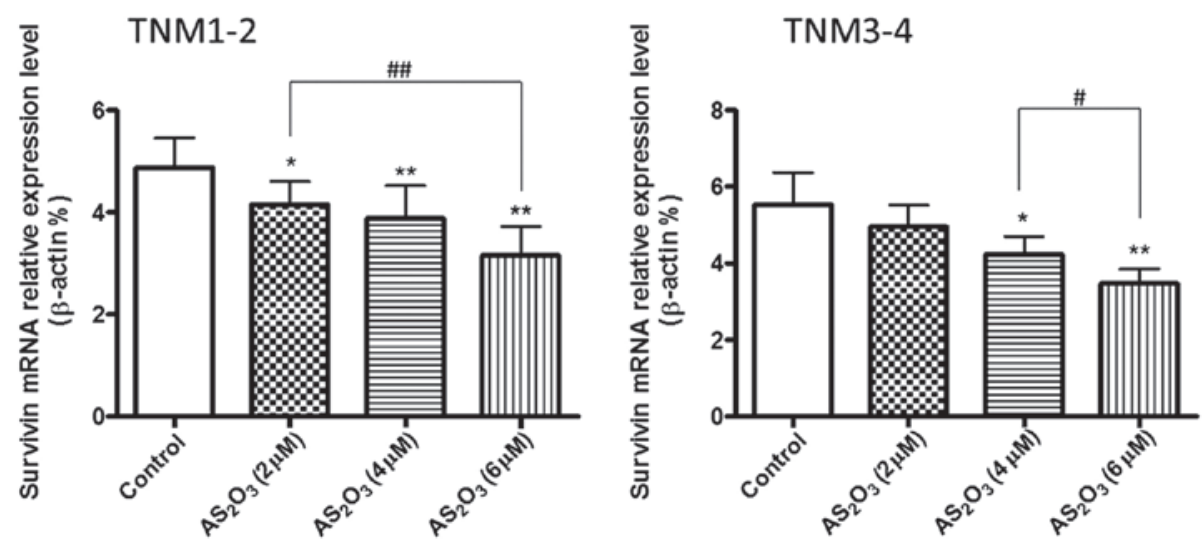

Figure 4. Relative mRNA expression levels of survivin in primary human adenoid cystic carcinoma cells from the lacrimal gland after $48 \mathrm{~h}$ treatment with $\mathrm{As}_{2} \mathrm{O}_{3}$. Results are expressed as the mean \pm standard deviation $(\mathrm{n}=5)$. ${ }^{*} \mathrm{P}<0.05$ and ${ }^{* *} \mathrm{P}<0.01$, vs. control; ${ }^{*} \mathrm{P}<0.05$ and ${ }^{\# \#} \mathrm{P}<0.01$, vs. As $\mathrm{O}_{3}(2 \mu \mathrm{M})$ or $\mathrm{As} \mathrm{O}_{3}(4 \mu \mathrm{M})$. TNM, tumor-node-metastasis; $\mathrm{As}_{2} \mathrm{O}_{3}$, arsenic trioxide.
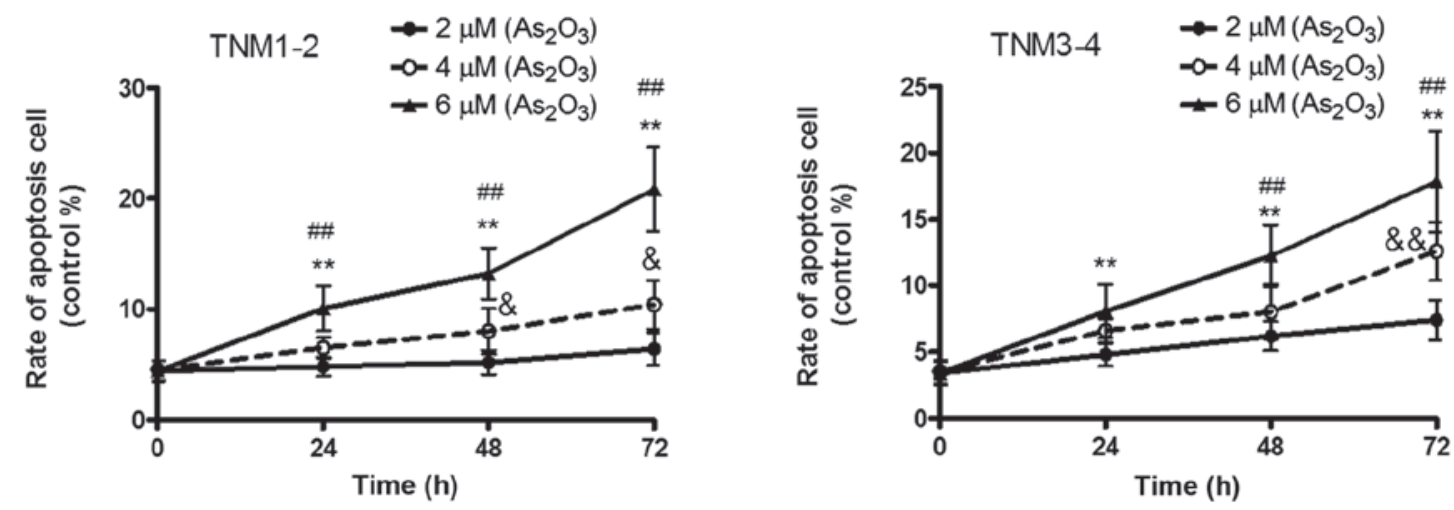

Figure 5. Treatment of primary human adenoid cystic carcinoma cells from the lacrimal gland with $\mathrm{As}_{2} \mathrm{O}_{3}$ resulted in a time- and dose-dependent increase in apoptotic cells. Results are expressed as the mean \pm standard deviation $(\mathrm{n}=5) .{ }^{* *} \mathrm{P}<0.01, \mathrm{As}_{2} \mathrm{O}_{3}(6 \mu \mathrm{M}) \mathrm{vs} . \mathrm{As}_{2} \mathrm{O}_{3}(2 \mu \mathrm{M}) ;{ }^{\# \#} \mathrm{P}<0.01, \mathrm{As}_{2} \mathrm{O}_{3}(6 \mu \mathrm{M})$ vs. As $\mathrm{O}_{3}$ $(4 \mu \mathrm{M})$; ${ }^{\circledR} \mathrm{P}<0.05$ and ${ }^{\& \&} \mathrm{P}<0.01, \mathrm{As}_{2} \mathrm{O}_{3}(4 \mu \mathrm{M})$ vs. $\mathrm{As}_{2} \mathrm{O}_{3}(2 \mu \mathrm{M})$. TNM, tumor-node-metastasis; $\mathrm{As}_{2} \mathrm{O}_{3}$, arsenic trioxide.

TNM3-4 group, particularly at a concentration of 4 and $6 \mu \mathrm{M}$ $\mathrm{As}_{2} \mathrm{O}_{3}$ (Fig. 4; $\mathrm{P}<0.05, \mathrm{P}<0.01$ ).

Effects of different doses of $\mathrm{As}_{2} \mathrm{O}_{3}$ treatment on cell apoptosis. After $72 \mathrm{~h}$ of treatment, $\mathrm{As}_{2} \mathrm{O}_{3}$ was demonstrated to dose-dependently decrease the cell viability in the TNM1-2 and TNM3-4 groups $(\mathrm{P}<0.05, \mathrm{P}<0.01)$, indicating that $\mathrm{As}_{2} \mathrm{O}_{3}$ was able to significantly promote cell apoptosis. In the TNM1-2 group, the apoptotic rate was shown to increase from 4.80 to $6.51 \%$, and finally to $10.06 \%$, according to the concentration of $\mathrm{As}_{2} \mathrm{O}_{3}(2,4$ and $6 \mu \mathrm{M})$ in $24 \mathrm{~h}$. Furthermore, the apoptotic rates at $48 \mathrm{~h}$ were $5.20,8.02$ and $13.24 \%$ for the various concentrations, respectively, and $6.40,10.41$ and $20.84 \%$ at $72 \mathrm{~h}$, respectively. In the TNM3-4 group, the 
apoptotic rates following treatment with 2, 4 and $6 \mu \mathrm{M} \mathrm{As}_{2} \mathrm{O}_{3}$ were $4.82,6.59$ and $8.06 \%$ at $24 \mathrm{~h}$, respectively, 6.20, 8.02 and $12.19 \%$ at $48 \mathrm{~h}$, respectively, and $7.40,12.59$ and $17.84 \%$ at 72 h, respectively (Fig. 5).

\section{Discussion}

Survivin is one of eight members of the inhibitor of apoptosis protein family, which was initially identified in 1997 (11). Although survivin is predominantly expressed in fetal tissues, little or no expression is observed in completely differentiated human tissues. However, multiple malignant tumor tissues, such as human ACC, have been shown to exhibit hyperexpression of survivin (12). In the present study, survivin was demonstrated to be highly expressed in ACC cells of the lacrimal gland, and the corresponding expression levels were shown to correlate with the TNM classification. The expression of survivin in the TNM3-4 group was significantly higher compared with the TNM1-2 group and control.

Survivin plays a vital role in the entire cell cycle since the protein exerts dual functions in inhibiting cell apoptosis and promoting cell proliferation (12). Survivin has been recognized as a putative biomarker and drug target for various types of tumor (9). However, the underlying mechanism remains unknown. A previous study hypothesized that survivin may block apoptosis via inhibiting caspase-3 and -7 (13). In addition, survivin has been proposed to interact with interleukin-3, Fas, Bax and p53 (14,15); however, the underlying mechanisms require further investigation. During mitosis, survivin exists as a multi-protein complex, known as the chromosomal passenger complex. By participating in this complex, survivin may promote cell proliferation by facilitating accurate sister chromatid segregation and the stabilization of microtubules in late mitosis (16). In the present study, silencing survivin expression using siRNA in primary cultured ACC cells of the lacrimal gland was shown to significantly decelerate the rate of cell proliferation, which may be attributed to the ability of survivin to inhibit apoptosis and promote proliferation.

$\mathrm{As}_{2} \mathrm{O}_{3}$ is a broad-spectrum anti-cancer drug that has been widely administered over a number of years. The compound can significantly suppress the growth of solid tumors, such as stomach and pulmonary carcinomas. The underlying mechanism is hypothesized to involve $\mathrm{As}_{2} \mathrm{O}_{3}$ initiating the mitochondria-mediated apoptosis pathway, which increases the production of reactive oxygen species, subsequently activating cytochrome $c$ pathway-induced apoptosis and thereby facilitating the mutation of mitochondrial DNA in the mitochondria (17). A previous study demonstrated that $\mathrm{As}_{2} \mathrm{O}_{3}$ was able to induce the apoptosis of ACC-2 cells, indicating a potential anti-adenocarcinoma effect of $\mathrm{As}_{2} \mathrm{O}_{3}$ (10). In the present study, $\mathrm{As}_{2} \mathrm{O}_{3}$ was demonstrated to dose-dependently inhibit the mRNA expression of survivin in primary cultured cells isolated from the tumor tissues of the TNM1-2 and TNM3-4 groups. Furthermore, $\mathrm{As}_{2} \mathrm{O}_{3}$ was shown to enhance the cell apoptosis rate in the TNM1-2 and TNM3-4 groups in a dose- and time-dependent manner. Therefore, the results of the present study indicate that $\mathrm{As}_{2} \mathrm{O}_{3}$ may exert an anti-LGACC effect.
In conclusion, to the best of our knowledge the present study is the first to demonstrate that survivin is expressed in the tumor tissues of patients with LGACC, and is positively associated with tumor deterioration. Furthermore, it was observed that $\mathrm{As}_{2} \mathrm{O}_{3}$ induces the apoptosis of LGACC cells by inhibiting survivin expression. Therefore, the results of the present study indicate an association between survivin and LGACC, with the overexpression of survivin suggesting a poor prognosis in patients with LGACC. Survivin may be useful as a diagnostic marker and a potential therapeutic target for the treatment of LGACC and $\mathrm{As}_{2} \mathrm{O}_{3}$ may be a feasible future therapy for the treatment of LGACC.

\section{References}

1. Kokemueller H, Eckardt A, Brachvogel P and Hausamen JE: Adenoid cystic carcinoma of the head and neck - a 20 years experience. Int J Oral Maxillofac Surg 33: 25-31, 2004.

2. Zhou Q, Chang H, Han YD, Gao Y and Liu HG: High-grade transformation in adenoid cystic carcinoma: A clinicopathologic study. Zhonghua Bing Li Xue Za Zhi 42: 106-110, 2013 (In Chinese).

3. Zeng J, Shi JT, Li B, Sun XL, An YZ, Li LQ, Gao F, Xu JP and Jonas JB: Epithelial tumors of the lacrimal gland in the Chinese: a clinicopathologic study of 298 patients. Graefes Arch Clin Exp Ophthalmol 248: 1345-1349, 2010.

4. Civit T, Klein O and Baylac F: Lacrimal gland epithelial tumors. Neurochirurgie 56: 152-157, 2010 (In French).

5. Lee JI, Kim YZ, Lee EH and Kim KH: Skull base invasion of adenoid cystic carcinoma of the lacrimal gland: a case report. J Korean Neurosurg Soc 44: 273-276, 2008.

6. McKenzie JA and Grossman D: Role of the apoptotic and mitotic regulator survivin in melanoma. Anticancer Res 32: 397-404, 2012.

7. Kanwar JR, Kamalapuram SK and Kanwar RK: Targeting survivin in cancer: Patent review. Expert Opin Ther Pat 20: 1723-1737, 2010.

8. Kanwar JR, Kamalapuram SK and Kanwar RK: Targeting survivin in cancer: The cell-signalling perspective. Drug Discov Today 16: 485-494, 2011.

9. Altieri DC: Survivin, cancer networks and pathway-directed drug discovery. Nat Rev Cancer 8: 61-70, 2008.

10. Zhang B, Mu HB, Xu XG, Liu W and Hu NR: Role of survivin gene on the apoptosis of adenoid cystic carcinoma-2 cells induced by arsenic trioxide. Hua Xi Kou Qiang Yi Xue Za Zhi 28: 246-249, 2010 (In Chinese).

11. Adida C, Crotty PL, McGrath J, Berrebi D, Diebold J and Altieri DC: Developmentally regulated expression of the novel cancer anti-apoptosis gene survivin in human and mouse differentiation. Am J Pathol 152: 43-49, 1998.

12. Ryan BM, O'Donovan N and Duffy MJ: Survivin: a new target for anti-cancer therapy. Cancer Treat Rev 35: 553-562, 2009.

13. Shin S, Sung BJ, Cho YS, Kim HJ, Ha NC, Hwang JI, Chung CW, Jung YK and Oh BH: An anti-apoptotic protein human survivin is a direct inhibitor of caspase-3 and -7. Biochemistry 40: 1117-1123, 2001.

14. Tamm I, Wang Y, Sausville E, Scudiero DA, Vigna N, Oltersdorf T and Reed JC: IAP-family protein survivin inhibits caspase activity and apoptosis induced by Fas (CD95), Bax, caspases and anticancer drugs. Cancer Res 58: 5315-5320, 1998.

15. Mirza A, McGuirk M, Hockenberry TN, Wu Q, Ashar H, Black S, Wen SF, Wang L, Kirschmeier P, Bishop WR, Nielsen LL, Pickett CB and Liu S: Human survivin is negatively regulated by wild-type p53 and participates in p53-dependent apoptotic pathway. Oncogene 21: 2613-2622, 2002.

16. Yang D, Welm A and Bishop JM: Cell division and cell survival in the absence of survivin. Proc Natl Acad Sci USA 101: 15100-15105, 2004.

17. Yang CH, Kuo ML, Chen JC and Chen YC: Arsenic trioxide sensitivity is associated with low level of glutathione in cancer cells. Br J Cancer 81: 796-799, 1999. 